\title{
PERFORMANCE, EMISSION, NOISE AND VIBRATION CHARACTERISTICS OF BIOGAS -DIESEL DUAL FUEL COMPRESSION IGNITION ENGINE
}

\author{
M. Ravi ${ }^{1}$ KCK Vijayakumar ${ }^{2}$, A. Murugesan ${ }^{3}$ R.Kannadhasan ${ }^{4}$ \\ ${ }^{1 \& 4}$ Department of Mechatronics Engineering, K.S.Rangasamy College of Technology, \\ Tiruchengode, Tamil Nadu, India \\ ${ }^{2}$ Vivekanandha Institute of Engineering and Technology for Women, \\ Tiruchengode, Tamil Nadu, India \\ ${ }^{3}$ Department of Mechanical Engineering, K.S.Rangasamy College of Technology, \\ Tiruchengode, Tamil Nadu, India \\ Corresponding author: ravierode@gmail.com
}

ABSTRACT

For decades, four-stroke compression ignition engines prove to be indispensable in major sectors of transport, agriculture, etc., and it will be very difficult to completely replace these heavy-duty workhorses in upcoming days. However, the present situation of four-stroke compression ignition engines is miserable and the future of these engines highly relies on meeting the emission norms that are being imposed every year. In this regard, renewable liquid fuels are capable of solving the problem of energy supply in a decentralized fashion and these fuels can simultaneously help in achieving environmental sustainability. In order to find a feasible solution to these issues, an endeavor has been made in this work to investigate the engine performance, emission, noise and vibration characteristics of Compression Ignition $(\mathrm{Cl})$ engine fuelled with biogas as a secondary fuel and diesel as primary fuel. In this work, the secondary and primary fuels are used to power the kirloskar single cylinder four stroke naturally aspirated water cooled diesel engine. The secondary fuel (biogas) at various quantities was mixed with air and fed into the intake manifold of the engine. Also, the supply of biogas to the engine is precisely controlled by electronic flow control valve. The different flow rates of the biogas are allowed to flow inside the engine with the air intake ratio of $0.075 \mathrm{gm} / \mathrm{s}, 0.1 \mathrm{gm} / \mathrm{s}, 0.125 \mathrm{gm} / \mathrm{s}, 0.15 \mathrm{gm} / \mathrm{s}$ and the analysis is done on each ratio. From the experimental results it was noted that at $0.125 \mathrm{gm} / \mathrm{s}$, biogas operation significantly reduces noise and vibration. Overall, from the experimental results it is concluded that the usage of biogas in dual fuel mode produces comparable engine performance and reduces noise and vibrations.

Keywords: Cl Engine; Emission; Electronic flow control; Biogas.

\section{Introduction}

In recent days, the depletion of easily accessible fossil fuel reserves and automotive emissions form the basis for investigation using alternative fuels. Also, the current energy situation throughout the world clearly indicates that renewable energy sources are eco-friendly and more feasible than non-renewable energy sources. In this regard, an importance is given worldwide to investigate the viability of renewable energy sources such as solar energy, wind energy, hydro energy and biogas [1]. Out of other renewable energy sources, biogas is particularly significant because of its possibility to be used in Internal Combustion (IC) engines [2]. The use of biogas in IC engine is investigated in this work with respect to engine performance, emissions, noise and vibration characteristics by using biogas as secondary fuel (manifold induction) and diesel as primary fuel (direct injection).

Energy is a compound system; energy-production and energy-conversion require systemic thinking for which a change of aspect is important. The most important view-point is to satisfy the energy demands with the lowest possible pressure on the environment. Furthermore, the ecological thinking should exist increasingly during the planning and operating of the different kinds of technical equipment and facilities [3]. In general, Biogas is produced by extracting chemical energy from organic material in a sealed container called digester. The generation of biogas concept of anaerobic digestion is also called as biological gasification [4]. It is a naturally occurring, microbial process that converts organic matter to methane and carbon dioxide. The average temperature of process is $40^{\circ} \mathrm{C}$. The chemical reaction takes place in the presence of methanogenic bacteria with water as an essential medium. The anaerobic digestion process as the name states, it functions without molecular oxygen. Ideally in a biogas plant there should be no oxygen within the digester. Oxygen removal from the digester is important for two main reasons. First, the presence of oxygen leads to the creation of water without methane. Second, the oxygen is source of a contamination in biogas and also a potential safety hazard. Due to the presence of oxygen, calorific value of biogas becomes low [4].

Nutt wal et al. [5] stated that the energy demand for gasoline and diesel fuel is as high as ever and imported petroleum products accounts for a larger proportion of the country's energy product. In developing country like India there is abundance of raw material for producing biogas. The biogas can be produced by anaerobic treatment and the main components are methane $\left(\mathrm{CH}_{4}\right)$ carbon dioxide $\left(\mathrm{CO}_{2}\right)$ and small amount of hydrogen $\left(\mathrm{H}_{2}\right)$, nitrogen $\left(\mathrm{N}_{2}\right)$, water vapour $\left(\mathrm{H}_{2} \mathrm{O}\right)$, and hydrogen sulphide $\left(\mathrm{H}_{2} \mathrm{~S}\right)$. Biogas approximately consists of $50-75 \%$ methane [6]. It is economical and its slurry can be used as organic manure. The use of methane separated from biogas as a fuel will substantially reduce the harmful engine emission and this will help to keep environment clean. The disadvantages of biogas are they contain impurities, not attractive and unstable. Packyam.et. al., 2013 [7] stated that the biogas production technology has led to the development of number of biogas appliances and the most promising among them is to meet energy requirement at the community level.[8] 
Several researchers have studied biogas combustion in dual fuel mode. An investigation by Karellas et. al., [9] portrays that the combustion of biogas is less efficient than the combustion of pure diesel fuel, particularly at high engine loads which presents an additional problem. However combustion with biogas as secondary fuel is more efficient. A recent study by Barik et al.,[1] revealed that better combustion characteristics can be obtained with dual fuel diesel engine operated with biogas and Karanja biodiesel. Violeta Makareviciene et al. [10] studied the exhaust gas emissions of a diesel engine running on a mixture of biogas and mineral diesel fuel. In this method, Exhaust gas recirculation (EGR) system was used to effectively control NOx emissions. In their study they noted that if the biogas was supplied without modifying engine control system, the total fuel consumption is increased and the thermal efficiency is decreased. Also, the concentration of pollutants, except NOx in the exhaust is increased.

In the past two decades, noise and vibrations have been regarded as significant health hazard. Regulations related to acoustic as well as vibration levels have therefore become more stringent [11]. In this regard, an attempt has been made in this work to study the magnitude of noise and vibration when the engine is operated on dual fuel mode

The literature review clearly indicated that biogas alone cannot be used as $\mathrm{Cl}$ engine fuel because of the less carbon content present in it. Also, the direct use of biogas will give rise to large amount of emissions. In order to avoid these problems, the dual fuel mode of biogas-diesel operation is suggested in this work. In this regard, adopts dual fuel mode of biogas and diesel with the amount of biogas input to the engine is to be controlled by the electronic flow control method.

\section{EXPERIMENTAL SETUP:}

In this work, a kirloskar single cylinder four stroke naturally aspirated water cooled diesel engine is used for estimating the performance and emission characteristics of diesel and diesel-biogas (Dual fuel) operation. Further, engine vibration and noise were analysed by vibration analyser and noise level meter. The experimental set-up is shown in figure 1 and the test engine specification is shown in table 1.

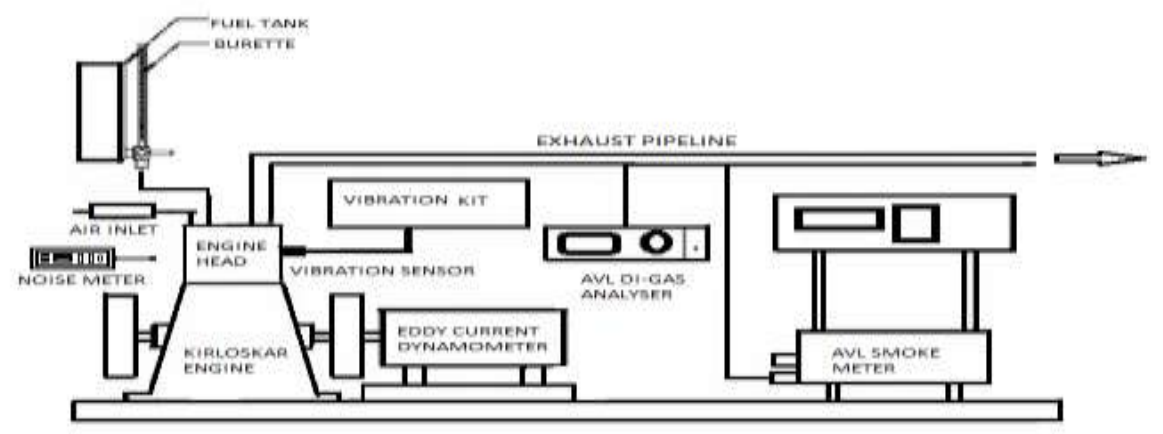

Figure 1 Experimental Set-up

In dual fuel mode, bio-gas is admitted into the engine along with air during the induction stroke. The bio-gas is compressed along with air during the compression stroke. At the end of compression stroke, small quantity of diesel is injected as pilot fuel which initiates combustion of bio-gas. Since biogas enters the engine as gaseous fuel, it eventually displaces the intake air which result in a lower volumetric efficiency. In order to overcome this issue, the bio-gas has to be mixed uniformly with air to avoid starting problem. For this purpose, blower is used in this work to mix the bio-gas and air. However, at the initial stage in order to overcome the starting difficulties the engine was started with diesel as warm up phase and thereafter the engine ran using bio-gas-diesel dual fuel

\section{TABLE 1 Engine Specifications}

\begin{tabular}{|l|l|}
\hline Make & Kirloskar \\
\hline Type & Vertical Engine \\
\hline Type of Cooling & Water \\
\hline Speed & $1500 \mathrm{rpm}$ \\
\hline Brake Power & $3.7 \mathrm{~kW}$ \\
\hline Bore Diameter & $80 \mathrm{~mm}$ \\
\hline Stroke Length & $110 \mathrm{~mm}$ \\
\hline Loading Method & Resistive loading \\
\hline
\end{tabular}


In the present work, the flow rate of bio-gas was controlled using electronic flow controller. The fuel flow rate is measured on volumetric basis (50 cc consumption) using burette and stop watch. An AVL gas analyzer and smoke meter were used to measure exhaust gas emissions and smoke. The experiment was conducted at constant speed of $1500 \mathrm{rpm}$. A temperature controller was used to maintain the temperature of biogas by controlling the supply to $500 \mathrm{~W}$ heater. Using the panel buttons the temperature of biogas can be adjusted as required. The temperature of biogas is fed to the controller with the help of $\mathrm{J}$-type thermocouple sensors. Based on the output of sensors the controller maintains the constant temperature of biogas as set initially. This gas then combines with the air using a blower of 0.09HP. Then the biogas and air mixture was sent to engine through the inlet manifold.

During testing, first diesel is used as fuel and the engine is run at different loads, second the biogas is mixed with inlet air with diesel as pilot fuel for ignition and third preheated biogas is mixed with inlet air with diesel as pilot fuel for ignition.

In the present case, the normal diesel fuel injection system still supplies a certain amount of diesel fuel. The engine however sucks and compresses a mixture of air and biogas fuel which has been prepared in external mixing devices. The mixture is then ignited together with the diesel fuel sprayed in. The amount of diesel fuel needed for operation on sufficient ignition is between $10 \%$ and $20 \%$ of the operation on diesel fuel alone. Due to the stoichiometric mixing of air and fuel, the emission is highly reduced and results in optimized efficiency. So, the air/fuel ratio is injected at different amounts by injected biogas. All other parameters and elements of diesel engine remain unchanged.

\section{RESULTS \& DISCUSSION}

In this work an endeavor has been made to compare the performance, emission, noise and vibration characteristics of $\mathrm{Cl}$ engine when operated with neat diesel and biogas-diesel dual fuel. Electronic flow control valve was used to supply biogas at $0.075 \mathrm{gm} / \mathrm{s}, 0.1 \mathrm{gm} / \mathrm{s}, 0.125 \mathrm{gm} / \mathrm{s}$ and $0.15 \mathrm{gm} / \mathrm{s}$ respectively.

\subsection{BRAKE THERMAL EFFICIENCY}

The variation of brake thermal efficiency (\%) with load (\%) for diesel and biogas-diesel dual fuel is shown in figure 2 . The brake thermal efficiency indicates the ability of the combustion system to accept the experimental fuel and provide a comparable means of assessing how fuel energy can be efficiently converted into mechanical output. In the present work, the brake thermal efficiency of diesel operated engine was noted to be more than dual fuel operation. This is because of the lower calorific value of biogas. In addition, the other factors like biogas residual gases, low combustion temperature and low flame propagation speed, higher total fuel flow rate during combustion and increased negative compression work caused by induction of large biogas air mixture should have contributed to the low thermal efficiency in dual fuel mode. However, brake thermal efficiency of biogas induction at $0.125 \mathrm{~g} / \mathrm{s}$ was noted to be comparable with diesel at full load than other experimental biogas mass flow rates.

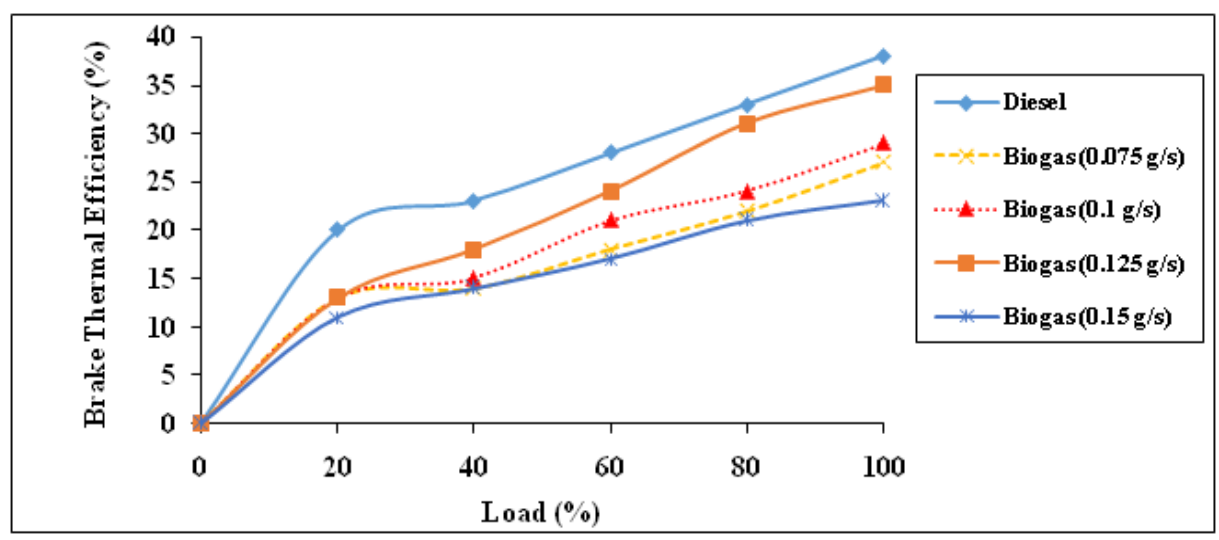

Figure 2: Variation of brake thermal efficiency Vs load

\subsection{Oxides of nitrogen( $\left.\mathrm{NO}_{\mathrm{x}}\right)$}

The Figure 3 shows the variation of nitric oxides emission with increase in load. As the load increases the overall fuel-air ratio increases resulting in an increase in the average gas temperature in the combustion chamber and higher $\mathrm{NO}_{x}$ formation. In this study, the Nox emission in the dual fuel mode is much higher in comparison to diesel mode as depicted in figure 3. This increase in $\mathrm{NO}_{x}$ for dual fuel operation is attributed to differences in the compressibility of the diesel fuel and biogas, which results in inadvertent advance in dynamic injection timing. Apart from this, in dual fuel mode the disassociation of $\mathrm{NO}_{2}$ in to $\mathrm{N}_{2}$ and $\mathrm{O}_{2}$ is suppressed by the higher temperature leading to formation of higher quantity of $\mathrm{NO}_{\mathrm{x}}$ in biogas-diesel dual fueled engine. 


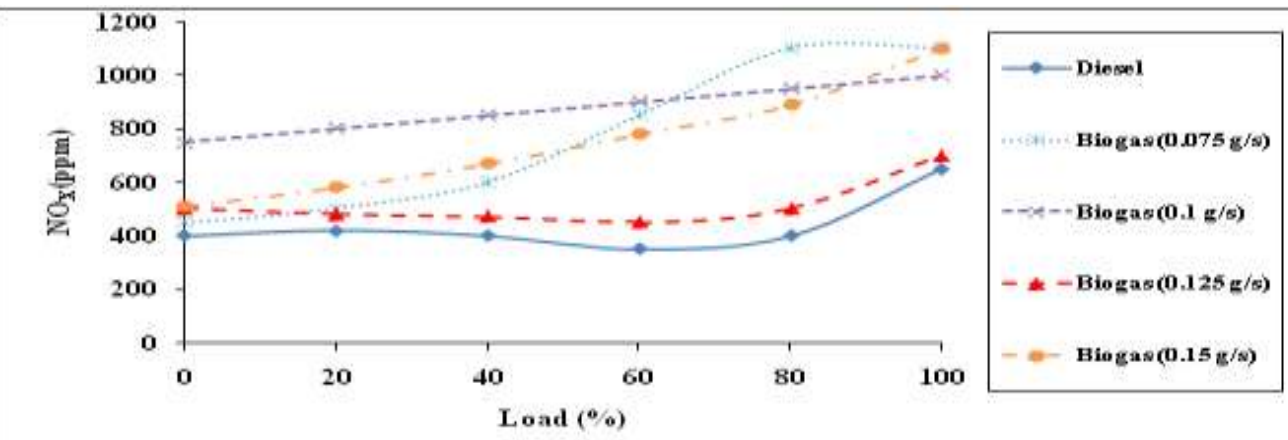

Figure 3: Variation of NOx Vs load

\subsection{SMOKE EMISSION}

The Figure 4 shows the variation of smoke emission with increase in load. The high smoke emission formed is an indicative of incomplete combustion. Thus, smoke forms essentially due to the deficit of oxygen in the fuel air mixture leading to the incomplete combustion. In this study, smoke emissions are higher in dual fuel mode in comparison to diesel mode because of lower stoichiometric flame of biogas than that of diesel .From this figure it is also observed that the smoke emission value is almost same for all the mixtures at full load condition.

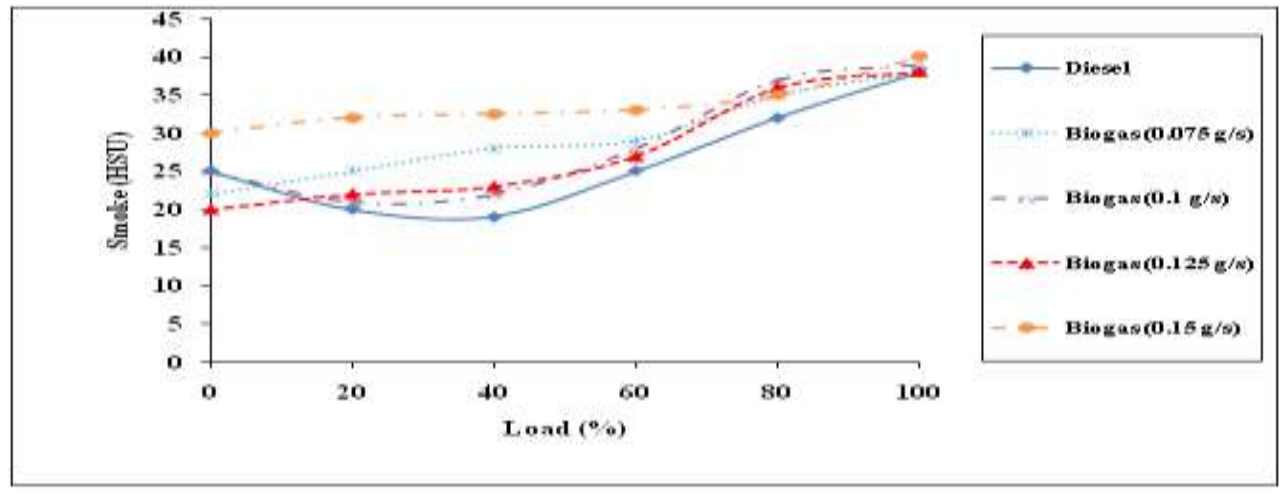

Figure 4: Variation of smoke Vs load

\subsection{Noise and vibration characteristics}

The variation of noise and vibration characteristics of diesel and biogas $(0.125 \mathrm{gm} / \mathrm{s})$ is compared in table 2 .

\section{Table 2: Noise and Vibration Comparison}

\begin{tabular}{|l|l|l|l|l|}
\hline Load & \multicolumn{2}{|l|}{ Diesel head } & \multicolumn{2}{l|}{ Biogas head } \\
\hline$\%$ & $\begin{array}{l}\text { Vibration(Hz) } \\
(\mathrm{Hz})\end{array}$ & $\begin{array}{l}\text { Noise } \\
(\mathrm{dB})\end{array}$ & $\begin{array}{l}\text { Vibration } \\
(\mathrm{Hz})\end{array}$ & $\begin{array}{l}\text { Noise } \\
(\mathrm{dB})\end{array}$ \\
\hline 0 & 165 & 96.4 & 170 & 97.2 \\
\hline 20 & 170 & 96.0 & 157 & 97.4 \\
\hline 40 & 179 & 96.8 & 166 & 96.3 \\
\hline 60 & 180 & 97.2 & 184 & 97.3 \\
\hline 80 & 184 & 97.4 & 180 & 97.1 \\
\hline 100 & 206 & 98 & 184 & 97.3 \\
\hline
\end{tabular}

At $100 \%$ loading Biogas produced less vibration and noise than diesel. The reason for vibration and noise decline with biogas can be due to more complete combustion behavior than diesel. In addition, some origins of mechanically induced noise caused by various forces resulting from the combination of combustion gas and inertia forces might have reduced vibration and noise in case of biogas operation. 


\section{CONCLUSION}

In the present experimental investigation the test were carried on kirloskar single cylinder four stroke engine. The controlled amount of biogas is mixed with air and is fed into the manifold of the engine. The amount of biogas input to the engine is controlled by electronic flow control valve at same engine speeds under the different load conditions. The engine performance and emission testing were done by using gas analyzer, smoke meter, vibration anlyser and noise level meter. At $0.125 \mathrm{gm} / \mathrm{s}$ of biogas induction comparable results with respect to engine performance and emission at full load were obtained. Furthermore, engine vibration and noise of biogas operated engine reduced when compared to diesel. Thus, the electronic flow control of biogas will safeguard the vehicle from acoustic emission and electronic flow will control the flow of fuel. The usage of electronic flow method produces better result.

\section{REFERENCES}

[1] www.renewableenergyworld.com

[2] Murphy Jd, Mccarthy K. 2005. The Optimal Production of Biogas for use as a Transport Fuel In Ireland 30: $2111-27$.

[3] Galal mg, Abdel MM,AalMA,Kady EL. 2002. A comparative study between diesel and dual-diesel engines: performance and emissions. Combust SciTechnol;174:241-56.

[4] Yoon SH, Lee CS. 2011. Experimental investigations on the combustion and exhaust emission characteristics of biogas-biodiesel dual-fuel combustion in a Cl engine. Fuel Process Technol;92-992-1000.

[5] Nutt wal, W.J.\&Manz, D.L. 2008. A new energy security paradigm for the twenty first century technological forecasting and social change 75:1247-59 .

[6] Karellas s,boukisl,kontopoulos G.Chandra R,vijay VK ,SubbaraoPMV,Khura TK. Performance evaluation of a constant speed IC engines on biogas, methane enriched biogas and biogas. Appl Energy;88:3969-77.2011

[7] Packyam S.Angelselva, Raja kumar S. 2013. Flow Analysis of Biogas in a Burner for Domestic Application:3; 656-668

[8] Abu Md. Abdul Wadud, Md. TousifZaman, FazlayRabbee\& Md. Rajibur Rahman Renewable Energy: An Ideal Solution of Energy Crisis and Economic Development in Bangladesh

[9] Karellas s,boukisl,kontopoulos G.Chandra R,vijay VK ,SubbaraoPMV,Khura TK. 2011. Performance evaluation of a constant speed IC engines on biogas ,methane enriched biogas and biogas. Appl Energy;88:3969-77.

[10] VioletaMakareviciene, EgleSendzikiene ,Saugirdaspukalskas,AlfredRimkus, RicardasVegeneris 2005. Performance and emission characteristics of biogas used in diesel engine operation

[11] Mathias Winberg "Noise and Vibration Control of Combustion Engine Vehicles" Series No 2005 ISBN:91-7295-062-5.

\section{Author' biography with Photo}

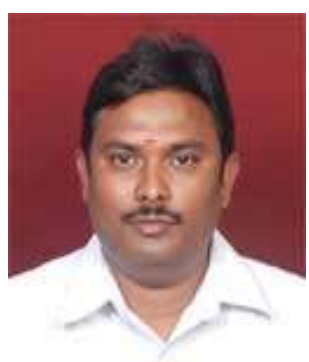

M.RAVI was born in India in 1979. He is presently working as associate Professor,Department of Mechatronics Engineering, K S Rangasamy College of Technology, Tiruchengode, India. He is pursuing his Ph.D in the faculty of Mechanical engineering from Anna University Chennai and he holds a ME degree in Mechatronics from Anna university, Chennai. And BE in Electrical and Electronics Engineering from Madras University, Chennai. He has published seven international journals and ten papers in international and national conferences. His research interest is alternate fuels 